\title{
Comparative Salinity Responses among Pigeonpea Genotypes and Their Wild Relatives
}

\author{
G. V. Subbarao, C. Johansen,* M. K. Jana, and J. V. D. K. Kumar Rao
}

\begin{abstract}
Soil salinity can be a major constraint to pigeonpea (Cajanus cajan (L.) Millsp.) in the regions where it is predominantly grown. This study was conducted to assess the extent of genetic variation for salinity tolerance in the germplasm of pigeonpea and its wild relatives. Solution culture experiments in a greenhouse and controlled environment chamber were conducted to screen a range of cultivated pigeonpea genotypes for ability to germinate and grow up to $60 \mathrm{~d}$ under saline conditions. Several wild relatives of pigeonpea were screened for salinity response in a sand culture system in a greenhouse. Among cultivated pigeonpea genotypes, ICPL 227 was one of the most tolerant and $\mathrm{HY} 3 \mathrm{C}$ one of the most sensitive genotypes tested. None of the pigeonpea genotypes tested were able to survive beyond $30 \mathrm{~d}$ at $8 \mathrm{dS} \mathrm{m}^{-1}$ or higher salinity levels. The extent of variation in salinity response among cultivated pigeonpea genotypes appeared too limited to warrant genetic enhancement of salinity tolerance. Among the wild relatives of pigeonpea, various species of Atylosia, Rynchosia, and Dunbaria showed a wide range of variation in their salinity tolerance (critical levels from 4 to 12 dS $\mathrm{m}^{-1}$ ): A. albicans (W.\& A.) Benth., and $A$. platycarpa could grow in a sand culture system at $12 \mathrm{dS} \mathrm{m}^{-1}$ and Rynchosia albiflora could not tolerate salinity levels above $4 \mathrm{dS} \mathrm{m}^{-1}$. These results suggest that using wild relatives for genetic improvement may increase salinity tolerance of pigeonpea.
\end{abstract}

$\mathrm{S}$ ALINITY IN SOIL or water is of increasing importance to agriculture because it causes a stress condition to crop plants. Carter (1975) reported that more than one-third of the world's irrigated area is affected by salinity. In India alone, where $90 \%$ of the world's pigeonpea is produced, an estimated 12 million ha of land has been affected by salinity or alkalinity (Sharma and Gupta, 1986). It is often suggested that genetic enhancement of salinity tolerance should supplement traditional methods of reclamation and drainage as part of an integrated approach towards economic utilization of saline soils.

G.V. Subbarao, C. Johansen, and J.V.D.K. Kumar Rao, Legumes Program, Int. Crops Res. Inst. for the Semi-Arid Tropics (ICRISAT), Patancheru, A.P. 502 324, India; and M.K. Jana, Dep. of Agric. Engineering, Indian Inst. of Technology, Kharagpur, West Bengal, 721302 , India. Submitted as ICRISAT Journal Article no. 1027. Received 29 Mar. 1990. *Corresonding author.

Published in Crop Sci. 31:415-418 (1991).
Genetic variation for salinity tolerance has been reported for pigeonpea and most crop species (Paliwal and Maliwal, 1973; Gururajarao et al., 1981; Keating and Fisher, 1985; Chauhan, 1987), but the extent and range of variation within a crop species generally seems to be limited. This is probably because most cultivated crop species have been selected in nonstress environments where salt tolerance traits, if any, would have been gradually lost from gene pools (Mudie, 1974; Maas and Nieman, 1978). If this hypothesis is correct, wild relatives of the crop species, which have not passed through the rigor of human selection, may provide a better chance of obtaining higher levels of tolerance to salinity.

Introduction of genes from the wild, salt-tolerant species can be used to enrich the gene pools of crop species (Tal, 1985). The lack of variation for salinity tolerance in the cultivated tomato [Lycopersicon esculentum $(\mathrm{L}$.) Mill.] can be overcome by making wide crosses with related species ( $L$. cheesmanii Riley and Solanum pennellii) that are highly salt tolerant (Tal and Shannon, 1983). The higher level of salinity tolerance of Elytrigia elongata (Host) Nevski, a wild wheat grass, was successfully transferred to the cultivated wheat (Triticum aestivum L.) and was expressed in the amphidiploids (Dvorak and Ross, 1986).

The extent of genetic diversity for salinity tolerance in pigeonpea germplasm has not been thoroughly explored. There are several wild relatives of pigeonpea belonging to the genera Atylosia, Rynchosia, Dunbaria, Paracalyx, Eriosema, and Flemingia (Remanandan et al., 1988), some of which can be crossed with the cultivated pigeonpea, but there is no information about their salinity tolerance. The objective of this investigation was to assess the exploitable genetic variation for salinity tolerance in germplasm of pigeonpea and its wild relatives.

\section{MATERIALS AND METHODS}

\section{Experiment 1}

One hundred and fifty pigeonpea genotypes were used in a preliminary screening study. These included germplasm lines from districts affected by salt in the Indian states of Uttar Pradesh, Punjab, and Maharashtra, as well as breed- 
ers' lines. Pigeonpea seeds were surface-sterilized with $20 \mathrm{~g}$ $\mathrm{kg}^{-1} \mathrm{HgCl}_{2}$ solution for $5 \mathrm{~min}$ and then thoroughly washed with deionized water. The surface-sterilized seeds were sown in growth pouches (blotting paper envelopes within a polythene bag) by placing 10 seeds in the cleft of each pouch. The pouches were suspended in clear acrylic tanks ( 90 by 75 by $50 \mathrm{~cm}$ ) and the bottom corners of the pouches were cut to expose a portion of the blotting paper to the nutrient solution in each tank. The outer surface of the tanks was painted black to prevent algal growth in the solution. A modified Arnon and Hoagland nutrient solution (0.25 strength) with $1.8 \mathrm{mM} \mathrm{NH}_{4} \mathrm{NO}_{3}$ was used as the growth medium. It was amended with $\mathrm{NaCl}+\mathrm{CACl}_{2}(1: 1 \mathrm{w} / \mathrm{w})$ for the $6 \mathrm{dS} \mathrm{m}^{-1}$ salinity treatment. This salinity level was determined as approximately critical for several pigeonpea genotypes in earlier studies (Subbarao, 1988). The control treatment, in which no salt was added to the nutrient solution, had an electrical conductivity (EC) of $0.36 \mathrm{dS} \mathrm{m} \mathrm{m}^{-1}$. The composition of the nutrient solution was (mM): 0.23 $\mathrm{KH}_{2} \mathrm{PO}_{4}, 0.52 \mathrm{KCl}, 0.25 \mathrm{MgSO}_{4}, 0.37 \mathrm{CaCl}_{2}, 0.0015 \mathrm{MnSO}_{4}$, $0.00023 \mathrm{ZnSO}_{4}, 0.00025 \mathrm{CuSO}_{4}, 0.001 \mathrm{H}_{3} \mathrm{BO}_{3}, 0.00005 \mathrm{Na}_{2}$ $\mathrm{MoO}_{4}$, and $0.04 \mathrm{NaFeEDTA}$. A split-plot design with three replicates was employed. Greenhouse mean temperatures were $28 / 22{ }^{\circ} \mathrm{C}$ (day/night) and relative humidity 60 to $70 \%$ (mean day and night). Tank positions were rerandomized each week to minimize spatial effects in the greenhouse.

Each tank was supplied with $100 \mathrm{~L}$ of treatment solution at sowing. The nutrient solution was aerated throughout the experimental period. Solutions were monitored daily for EC and adjusted to the required level by adding an appropriate amount of deionized water. Treatment solutions were replaced every week. Tank tops were covered with black cotton cloth until 7 days after sowing (DAS) to ensure uniform seed germination and seedling emergence. Seedlings were thinned to five per pouch at $10 \mathrm{DAS}$, at which time germination counts were also made. Plants were allowed to grow until 60 DAS.

\section{Experiment 2}

Ten pigeonpea genotypes selected for tolerance or sensitivity in Exp. 1, were further examined at six salinity levels: $0,5,6,7,8$, and $9 \mathrm{dS} \mathrm{m}^{-1}$. The plant culture method was as described for Exp. 1, but one tank was used for each salinity level and four replicates of each genotype were included in each tank. The experiment was conducted in a controlled environment growth chamber where temperatures were $28 / 22^{\circ} \mathrm{C}$ (day/night), relative humidity 60 to $70 \%$, phytosynthetically active radiation (PAR) 100 to 120 $\mathrm{W} / \mathrm{m}^{-2}$ and photoperiod $14 \mathrm{~h}$. Plants were harvested at 50 DAS.

\section{Experiment 3}

Four wild relatives of pigeonpea, $A$. scarabaeoides, $A$. platycarpa, $R$. albiflora, and $D$. ferruginea, along with a tolerant (ICPL 227) and a sensitive (HY 3C) pigeonpea genotype, were selected for this study. To promote germination, seeds of these wild relatives were scarified by nicking the testa with a scalpel. Seeds were then surface-sterilized and germinated on water-absorbent blotting paper. The germination rolls were prepared from blotting papers $(15$ by $10 \mathrm{~cm})$, in which seeds were centrally arranged and then rolled up. The rolls were then placed in plastic bags, moistened with distilled water and placed in an incubator at $28^{\circ} \mathrm{C}$.

The growth medium consisted of sieved river sand, washed and soaked in acid solution ( $\mathrm{pH} \mathrm{1-2)} \mathrm{for} 24 \mathrm{~h}$, and then thoroughly washed with tap water. The sand was dried and placed in 18-cm-diam. polypropylene pots $(2.5 \mathrm{~kg}$ sand pot $^{-1}$ ), which were subsequently steam sterilized. Seeds for each wild species were germinated before being sown, while for cultivated pigeonpea the seeds were surface-sterilized, but not germinated. Each pot surface was covered with $\mathbf{5 0}$ $\mathrm{g}$ of polythene beads to minimize evaporation. Seedlings were thinned to four per pot at 10 DAS. The nutrient solution was as for Exp. 1, with salinity treatments of $0,4,6$, 8 , and $10 \mathrm{dS} \mathrm{m}^{-1}$ applied as $\mathrm{NaCl}+\mathrm{CaCl}_{2}(1: 1 \mathrm{w} / \mathrm{w})$. The experiment was conducted in a greenhouse, with four replicates in a randomized complete-block design, using conditions similar to those in Exp. 1.

Pots were irrigated with deionized water until 13 DAS. At $14 \mathrm{DAS}$, an initial salinity level of $4 \mathrm{dS} \mathrm{m}^{-1}$ was imposed by flushing each pot with $1 \mathrm{~L}$ of $4 \mathrm{dS} \mathrm{m}^{-1}$ solution. To minimize salt shock to the seedlings for the $6 \mathrm{dS}-1$ and higher salinity treatments, the initial salt level of $4 \mathrm{dS} \mathrm{m}^{-1}$ was

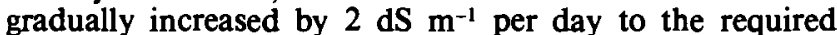
levels. Nutrient solution alone was used for flushing the 0 salinity treatment (control). Every 4 d, pots were flushed with treatment solutions ( $\left.250 \mathrm{~mL}^{\text {pot }}{ }^{-1}\right)$, to avoid salt build up. Pot positions were also randomized within each block every $4 d$ and evapotranspirational losses compensated daily with deionized water. Plants were harvested at 55 DAS. Shoots and roots were dried at $70^{\circ} \mathrm{C}$ for $48 \mathrm{~h}$ and dry weights recorded.

\section{Experiment 4}

Ten species of Atylosia (A. albicans, A. goensis, A. acutifolia, $A$. cajanifolia, $A$. grandifolia, $A$. lineata, $A$. lanceolata, $A$. reticulata, $A$. sericea, and $A$. volubilis) were grown for 55 d at salinity levels of $0,4,6,8$, and $10 \mathrm{dS} \mathrm{m}^{-1}$ following the experimental details and growth conditions described for Exp. 3.

\section{Statistics}

Data were subjected to analysis of variance and least significant differences at $P=0.05$ for the interaction term are quoted in the tables.

\section{RESULTS AND DISCUSSION}

Genetic variation in salinity response is a prerequisite for improving crop salinity tolerance (Shannon, 1985). In pigeonpea, there were significant differences among genotypes in their ability to germinate at a 6 $\mathrm{dS} \mathrm{m^{-1 }}$ salinity level. Among 150 genotypes tested (data presented only for selected genotypes), germination in the saline medium was as good as in the control (non-saline) in ICP 8695, ICP 11878, ICPL 228, ICPL 329, and ICP 8007 (Table 1), whereas ICP 8705 showed the maximum reduction $(28 \%)$ at $6 \mathrm{dS}$ $\mathrm{m}^{-1}$. Genotypic differences in pigeonpea for germination under saline conditions have also been reported by Paliwal and Maliwal (1973) and Gururajarao et al. (1981). At germination, pigeonpea appears to be relatively more tolerant to salinity than at later growth stages. At 8 and $9 \mathrm{dS} \mathrm{m}^{-1}$, none of the tested genotypes could survive beyond 4 wk (data not shown), even though germination was $\approx 60$ to $70 \%$ in most genotypes (Table 2).

There was variation among pigeonpea genotypes in survival, growth, and leaf necrosis at $6 \mathrm{dS} \mathrm{m}^{-1}$ (Table 1). In genotypes ICP 8695, ICP 8594, ICP 8659, and ICP 11876, survival was as good as in the control. There was $>70 \%$ mortality in some other genotypes, and $90 \%$ mortality was observed in ICP 8663. A breeders line, ICPL 227, produced dry matter equivalent to $71 \%$ of its control, without leaf necrosis, and 
showed 95\% survival. In contrast, pigeonpea genotypes ICP 11795, ICP 11796, ICP 8663, and HY 3C were the most adversely affected at $6 \mathrm{dS} \mathrm{m} \mathrm{m}^{-1}$; the growth reduction in them was $>80 \%$ and mortality $>60 \%$. The plants also showed severe leaf necrosis (Table 1).

Most genotypic variation for salinity tolerance in pigeonpea appeared to be confined to a narrow range of salinity levels, between 5 and $7 \mathrm{dS} \mathrm{m}^{-1}$ (Tables 3 and 4). There were no substantial differences in growth, survival, and leaf necrosis status between the most-tolerant (ICPL 227, ICP 8594, ICP 8659, ICP 10103, and ICPL 112) and the least-tolerant (HY 3C, ICP 8663, ICP 3783, ICP 9080, and ICP 11772) genotypes at $5 \mathrm{dS} \mathrm{m}^{-1}$ (Tables 3 and 4). None of the mosttolerant pigeonpea genotypes were able to survive at $\geq 8 \mathrm{dS} \mathrm{m}^{-1}$ in the hydroponic system. At $7 \mathrm{dS} \mathrm{m}^{-1}$ these tolerant genotypes suffered a growth reduction of $\approx 50 \%$. In many of the sensitive genotypes the growth was about $50 \%$ of the control at $5 \mathrm{dS} \mathrm{m}^{-1}$. Keating and Fisher (1985) observed a 50\% growth reduction in two pigeonpea varieties within a range of 4.9 to $5.4 \mathrm{dS} \mathrm{m}^{-1}$.

Genotypic variation of this magnitude, which is confined to a narrow range of salinity levels, may not be sufficient for genetic improvement of salinity tolerance in pigeonpea. Field salinity is a dynamic phenomenon in which salt concentrations may change across time and space, and genotypes selected for saline conditions should perform reasonably well across a range of salinity levels. In the present study, only 150 genotypes out of $>10000$ germplasm lines available in pigeonpea (Remanandan et al., 1988) were evaluated. The chances of obtaining a wider range of variation in salinity tolerance may still exist. Salinity tolerance has been increased through induced mutations (Langridge, 1958; Ashraf et al., 1987), but this method has its limitations (Nilan et al., 1969).

Table 1. Effect of salinity on germination, survival, growth and leaf damage (LD: yes $=$ necrosis present, no $=$ necrosis absent) of selected pigeonpea genotypes in solution culture (Exp. 1).

\begin{tabular}{|c|c|c|c|c|c|}
\hline \multirow[b]{2}{*}{ Genotype } & \multirow{2}{*}{$\begin{array}{l}\text { Germination } \\
\text { at } 6 \mathrm{dS} \mathrm{m} \mathrm{m}^{-1}\end{array}$} & \multirow{2}{*}{$\begin{array}{l}\text { Survival at } \\
6 \mathrm{dS} \mathrm{m}^{-1}\end{array}$} & \multicolumn{2}{|c|}{$\begin{array}{c}\text { Shoot dry matter } \\
\left(\mathrm{mg} \mathrm{plant}^{-1}\right)\end{array}$} & \multirow[b]{2}{*}{ LD } \\
\hline & & & Control & $6 \mathrm{dS} \mathrm{m}^{-1}$ & \\
\hline & $\%$ & $\%$ & & & \\
\hline $\begin{array}{l}\text { ICP } 8695 \\
\text { ICP 8594 } \\
\text { ICP } 8659 \\
\text { ICP 11876 } \\
\text { ICPL } 227 \\
\text { ICP } 10103 \\
\text { ICPL 112 } \\
\text { ICP } 11878 \\
\text { ICPL } 228 \\
\text { ICPL } 329 \\
\text { ICP } 8007 \\
\text { ICP 8705 } \\
\text { ICP } 11795 \\
\text { ICP } 11772 \\
\text { ICP 3783 } \\
\text { ICP 11796 } \\
\text { ICP 9080 } \\
\text { HY 3C } \\
\text { ICP 8663 } \\
\text { LSD (0.05) }\end{array}$ & $\begin{array}{lc}80 & (100) \dagger \\
75 & (90) \\
77 & (93) \\
73 & (78) \\
85 & (94) \\
73 & (78) \\
80 & (92) \\
77 & (100) \\
77 & (100) \\
83 & (100) \\
80 & (100) \\
63 & (72) \\
75 & (83) \\
80 & (82) \\
80 & (89) \\
70 & (80) \\
77 & (89) \\
72 & (88) \\
67 & (92) \\
11 & \end{array}$ & $\begin{array}{r}100 \\
100 \\
100 \\
100 \\
95 \\
86 \\
80 \\
76 \\
86 \\
80 \\
46 \\
46 \\
40 \\
35 \\
30 \\
26 \\
26 \\
25 \\
10 \\
6\end{array}$ & $\begin{array}{l}258 \\
659 \\
454 \\
287 \\
352 \\
390 \\
567 \\
327 \\
303 \\
290 \\
185 \\
267 \\
254 \\
288 \\
450 \\
303 \\
217 \\
351 \\
373 \\
37(7.9)\end{array}$ & $\begin{array}{l}132(51) \dagger \\
377(58) \\
240(58) \\
165(57) \\
256(71) \\
240(61) \\
287(51) \\
170(52) \\
121(40) \\
121(42) \\
42(22) \\
60(23) \\
36(15) \\
60(21) \\
90(20) \\
46(15) \\
63(29) \\
55(16) \\
58(16)\end{array}$ & $\begin{array}{l}\text { yes } \\
\text { no } \\
\text { no } \\
\text { no } \\
\text { no } \\
\text { no } \\
\text { no } \\
\text { yes } \\
\text { no } \\
\text { yes } \\
\text { yes } \\
\text { yes } \\
\text { yes } \\
\text { yes } \\
\text { yes } \\
\text { yes } \\
\text { yes } \\
\text { yes } \\
\text { yes }\end{array}$ \\
\hline
\end{tabular}

$\uparrow$ Figures in parentheses are percentages of control.
Various species of Atylosia, Rynchosia, and Dunbaria showed a wide range of variation in their salinity tolerance, from 4 to $12 \mathrm{dS} \mathrm{m}^{-1}$ (Tables 5 and 6). Atylosia platycarpa and $A$. albicans were shown in previous experiments (Subbarao, 1988) to tolerate and grow at salt concentrations of $12 \mathrm{dS} \mathrm{m}^{-1}$. Atylosia platycarpa was able to flower and produce pods at all salinity levels, including $12 \mathrm{dS} \mathrm{m}^{-1}$ in this study. Rynchosia albiflora was at the other extreme, being able to withstand salinity levels only $\leq 4 \mathrm{dS} \mathrm{m}^{-1}$.

Table 2. Effect of different levels of salinity on germination of selected pigeonpea genotypes in solution culture (Exp. 2).

\begin{tabular}{|c|c|c|c|c|c|c|}
\hline \multirow[b]{2}{*}{ Genotype } & \multicolumn{6}{|c|}{ Salinity level $\left(\mathrm{dS} \mathrm{m}^{-1}\right)$} \\
\hline & $\mathbf{0}$ & 5 & 6 & 7 & 8 & 9 \\
\hline & & & & & & \\
\hline $\begin{array}{l}\text { ICP } 8594 \\
\text { ICP } 8659 \\
\text { ICP } 10103 \\
\text { ICPL } 112 \\
\text { ICPL } 227 \\
\text { ICP } 8663 \\
\text { ICP } 3783 \\
\text { ICP 9080 } \\
\text { ICP } 11772 \\
\text { HY 3C }\end{array}$ & $\begin{array}{l}85 \\
90 \\
95 \\
95 \\
90 \\
80 \\
85 \\
90 \\
90 \\
95\end{array}$ & $\begin{array}{ll}85 & (100) \dagger \\
78 & (87) \\
85 & (89) \\
83 & (87) \\
85 & (94) \\
75 & (94) \\
70 & (82) \\
78 & (87) \\
80 & (89) \\
80 & (84)\end{array}$ & $\begin{array}{l}75(88) \\
75(83) \\
73(77) \\
75(79) \\
85(94) \\
70(88) \\
63(74) \\
75(83) \\
70(78) \\
80(84)\end{array}$ & $\begin{array}{l}75(88) \\
70(78) \\
75(79) \\
70(74) \\
75(83) \\
63(79) \\
58(68) \\
70(78) \\
65(72) \\
70(74)\end{array}$ & $\begin{array}{l}70(82) \\
65(72) \\
70(74) \\
65(68) \\
70(78) \\
60(75) \\
50(59) \\
65(72) \\
60(67) \\
65(68)\end{array}$ & $\begin{array}{l}70(82) \\
60(67) \\
65(68) \\
60(63) \\
70(78) \\
55(69) \\
40(47) \\
60(67) \\
60(67) \\
60(63)\end{array}$ \\
\hline
\end{tabular}

$\operatorname{LSD}(0.05)=10.5$

† Figures in parentheses are percentages of control.

Table 3. Effect of different levels of salinity on the survival and leaf damage (LD: yes $=$ necrosis present, no $=$ necrosis absent) of selected pigeonpea genotypes at 50 DAS (Exp. 2).

\begin{tabular}{lccccc}
\hline & \multicolumn{3}{c}{ Salinity level (dS m $\left.{ }^{-1}\right) \dagger$} \\
\cline { 2 - 3 } \cline { 5 - 6 } \cline { 5 - 6 } Genotype & \multicolumn{2}{c}{6} & & \multicolumn{2}{c}{7} \\
\cline { 2 - 3 } \cline { 5 - 6 } & Survival & LD & & Survival & LD \\
\hline ICP 8594 & $\%$ & & & $\%$ & \\
ICP 8659 & 100 & no & & 90 & no \\
ICP 10103 & 93 & no & & 93 & no \\
ICPL 112 & 95 & no & & 90 & no \\
ICPL 227 & 80 & no & & 70 & no \\
ICP 8663 & 100 & no & & 93 & no \\
ICP 3783 & 30 & yes & & 10 & yes \\
ICP 9080 & 40 & yes & & 20 & yes \\
ICP 11772 & 15 & yes & & 10 & yes \\
HY 3C & 35 & yes & & 20 & yes \\
LSD $(0.05)=7$ & 30 & yes & & 20 & yes
\end{tabular}

$\operatorname{LSD}(0.05)=7$

$\uparrow$ All genotypes had $100 \%$ survival and no leaf damage at 0 and $5 \mathrm{dS} \mathrm{m}^{-1}$, but none survived at 8 and $9 \mathrm{dS} \mathrm{m}^{-1}$ beyond 30 days after sowing.

Table 4. Effect of salinity on shoot dry matter of selected pigeonpea genotypes in solution culture at 50 DAS (Exp. 2).

\begin{tabular}{|c|c|c|c|c|}
\hline \multirow[b]{2}{*}{ Genotype } & \multicolumn{4}{|c|}{ Salinity level (dS m-1) } \\
\hline & $\mathbf{0}$ & 5 & 6 & 7 \\
\hline & & - mg & $\mathrm{nt}^{-1}-$ & \\
\hline $\begin{array}{l}\text { ICP } 8594 \\
\text { ICP } 8659 \\
\text { ICP } 10103 \\
\text { ICPL } 112 \\
\text { ICPL } 227 \\
\text { ICP } 8663 \\
\text { ICP } 3783 \\
\text { ICP } 9080 \\
\text { ICP } 11772 \\
\text { HY 3C } \\
\text { LSD }(0.05)=95\end{array}$ & $\begin{array}{l}725 \\
955 \\
662 \\
741 \\
558 \\
544 \\
725 \\
600 \\
690 \\
646\end{array}$ & $\begin{array}{l}439(59) \dagger \\
575(60) \\
429(63) \\
446(60) \\
391(70) \\
326(60) \\
370(51) \\
300(50) \\
352(51) \\
265(41)\end{array}$ & $\begin{array}{l}388(53) \\
525(55) \\
330(50) \\
355(48) \\
362(65) \\
162(30) \\
255(35) \\
180(30) \\
140(20) \\
122(19)\end{array}$ & $\begin{array}{r}363(50) \\
459(48) \\
264(40) \\
312(42) \\
277(50) \\
96(18) \\
107(15) \\
31(5) \\
70(10) \\
65(10)\end{array}$ \\
\hline
\end{tabular}

† Figures in parentheses are percentages of control $(\operatorname{LSD}(0.05)=7.6)$. 
Table 5. Effect of salinity on the shoot dry matter of wild relatives of pigeonpea (Atylosia, Rynchosia and Dunbaria spp.), ICPL 227 and $\mathrm{HY} 3 \mathrm{C}$ at 55 DAS in sand culture (Exp. 3).

\begin{tabular}{|c|c|c|c|c|c|}
\hline \multirow[b]{2}{*}{ Species/genotype } & \multicolumn{5}{|c|}{ Salinity level (dS $\left.\mathbf{m}^{-1}\right)$} \\
\hline & 0 & 4 & 6 & 8 & 10 \\
\hline & & & g pot & & \\
\hline $\begin{array}{l}\text { A. platycarpa } \\
\text { A. scarabaeoides } \\
R \text {. albiflora } \\
\text { D. fermginea } \\
\text { ICPL } 227 \\
\text { HY } 3 C \\
\text { LSD }(0.05)=0.33\end{array}$ & $\begin{array}{r}16.25 \\
1.09 \\
0.73 \\
0.76 \\
4.11 \\
4.11\end{array}$ & $\begin{array}{l}13.17(81) \dagger \\
0.77(71) \\
0.19(26) \\
0.53(70) \\
2.88(70) \\
2.30(51)\end{array}$ & $\begin{array}{r}12.35(76) \\
0.56(51) \\
0.15(21) \\
0.32(42) \\
2.47(61) \\
1.23(30)\end{array}$ & $\begin{array}{r}10.08(62) \\
0.30(28) \\
0.08(12) \\
0.24(31) \\
1.64(41) \\
0.65(16)\end{array}$ & $\begin{array}{l}8.45(52) \\
0.11(10) \\
0.07(9) \\
0.06 \quad(8) \\
0.41(9) \\
0.21 \quad(5)\end{array}$ \\
\hline
\end{tabular}

$\dagger$ Figures in parentheses are percentages of control (LSD $(0.05)=6.0)$.

Table 6. Response of shoot dry matter of Atylosia species to salinity at 55 DAS in sand culture (Exp. 4).

\begin{tabular}{|c|c|c|c|c|c|}
\hline \multirow[b]{2}{*}{ Atylosia species } & \multicolumn{5}{|c|}{ Salinity level (dS m-1) } \\
\hline & $\mathbf{0}$ & 4 & 6 & 8 & 10 \\
\hline & & & & & \\
\hline \multirow{11}{*}{$\begin{array}{l}\text { A. albicans } \\
\text { A. sericea } \\
\text { A. cajanifolia } \\
\text { A. volubilis } \\
\text { A. reticulata } \\
\text { A. grandifolia } \\
\text { A. lineata } \\
\text { A. goensis } \\
\text { A. lanceolata } \\
\text { A. acutifolia } \\
\text { LSD }(0.05)=0.60\end{array}$} & 7.9 & 6. & 5.85 & 5. 10 & $3.81(48)$ \\
\hline & 9. & & & & 3) \\
\hline & 8.70 & 6.3 & 5.1 & 4.0 & $2.87(34)$ \\
\hline & & & & & $2.53(25)$ \\
\hline & 4. & 3.2 & $3.19(67)$ & 1.73 & 0.43 (9) \\
\hline & 3. & & 1.65 & 0.79 & $0.16 \quad(4)$ \\
\hline & 7. & & & 1.86 & 0.71 (10) \\
\hline & 8.31 & & 3.94 (48) & $0.83(10)$ & 0.42 (5) \\
\hline & 5.7 & & & & 0.29 (5) \\
\hline & 3.48 & $1.42(41)$ & $1.05(30)$ & 0.43 (12) & $0.17 \quad(5)$ \\
\hline & & & & & \\
\hline
\end{tabular}

† Figures in parentheses are percentages of control $(\operatorname{LSD}(0.05)=8.5)$.

Among the 15 wild relatives tested, $A$. platycarpa, $A$. albicans, $A$. sericea, and $A$. cajanifolia were distinctly superior in their salinity tolerance compared with the most tolerant pigeonpea genotype ICPL 227. This certainly enhances the possibilities of increasing salinity tolerance of pigeonpea by introgressing the higher levels of tolerance from these wild relatives. Atylosia platycarpa is incompatible for direct hybridization with cultivated pigeonpea, and bridging techniques are necessary to transfer not only salnity tolerance but also other desirable traits of this species (Dundas et al., 1989); however, $A$. albicans, which has the same level of tolerance as $A$. platycarpa, is compatible with the cultivated pigeonpea and the higher level of tolerance could thus be directly transferred to pigeonpea. The tolerance in $A$. sericea and $A$. cajanifolia is similarly transferable to pigeonpea. The remaining wild relatives $(A$. scarabaeoides, $A$. volubilis, $A$. reticulata, $A$. grandifolia, $A$. lineata, $A$. goensis, $A$. lanceolata, $A$. acutifolia, $D$. ferruginea, and $R$. albiflora) are either similar or inferior to ICPL 227 in their salinity tolerance; however, this study is based on only one accession from each species. Considering the large number of accessions available within each species
(Remanandan et al., 1988), even higher levels of salinity tolerance than what has so far been identified in $A$. platycarpa and $A$. albicans are possible. This could be realized through systematic evaluation of all accessions in wild species showing salinity tolerance.

\section{ACKNOWLEDGMENTS}

The authors are grateful to Dr. D.L. Oswalt and Dr. F.B. Lopez, ICRISAT, India, for helpful suggestions on the manuscript.

\section{REFERENCES}

Ashraf, M., T. McNeilly, and A.D. Bradshaw. 1987. Selection and heritability of tolerance to sodium chloride in four forage species. Crop Sci. 27:232-234

Carter, D.L. 1975. Problems of salinity in agriculture. p. 25-35. In A. Poljakoff-Mayber and J. Gale (ed.) Plants in saline environments. Springer-Verlag, Berlin.

Chauhan, Y.S. 1987. Screening for tolerance to salinity and waterlogging: Case studies with pigeonpea and chickpea. p. 93-103 In ICRISAT (ed.) Adaptation of chickpea and pigeonpea to abiotic stresses. Proc. Consultants' Workshop, ICRISAT, 19-21 Dec 1984. India. ICRISAT, Patancheru, India.

Dundas, I.S., K.B. Saxena, Laxman Singh, and D.G. Faris. 1989. Crossability relationships and possible bridging routes involving Asian and Australian Atylosia species. Int. Pigeonpea Newsl. 9:45 .

Dvorak, J., and K. Ross. 1986. Expression of tolerance of $\mathrm{Na}, \mathrm{K}$, $\mathrm{Mg}, \mathrm{Cl}$ and $\mathrm{SO}_{4}$ ions and sea water in the amphidiploids of Triticum aestivum $\times$ Elytrigia elongata. Crop Sci. 26:658-660.

Gururajarao, G., K.V. Ramanarao, and G. Rajeswararao. 1981. Studies on salt tolerance of pigeonpea cultivars: I. Germination, seedling growth and some physiological changes. Proc. Indian Acad. Sci. (Plant Sci) 90:555-559.

Keating, B.A., and M.J. Fisher. 1985. Comparative tolerance of tropical grain legumes to salinity. Aust. J. Agric. Res. 36:373-383.

Langridge, J. 1958. An osmotic mutant of Arabidopsis thaliana. Aust. J. Biol. Sci. 11:457-470.

Maas, E.V., and R.H. Nieman. 1978. Physiology of plant tolerance to salinity. p. 277-299. In G.A. Jung (ed.) Crop tolerance to suboptimal land conditions. ASA Spec. Publ. 32. ASA, CSSA, and SSSA, Madison, WI.

Mudie, P.J. 1974. The potential economic use of halophytes. p. 565597. In R.J. Reimold, and W.H. Queen (ed.) Ecology of halophytes. Academic Press, New York.

Nilan, R.A., A. Kleinhofs, and E.G. Sideris. 1969. Structural and biochemical concepts of mutants in flowering plants. p. 35-49. In International Atomic Energy Agency (ed.) Induced mutations in plants. Proc. IAEA/FAO Symp., Pullman, WA. 14-18 July, 1969. IAEA, Vienna.

Paliwal, K.V., and G.L. Maliwal. 1973. Salt tolerance of some arhar (Cajanus indicus) and cowpea (Vigna sinensis) varieties at germination and seedling stages. Ann. Arid Zone 12:135-144.

Remanandan, P., D.V.S.S.R. Sastry, and M.H. Mengesha. 1988. ICRISAT pigeonpea germplasm catalogue, passport information. ICRISAT, Patancheru, India.

Shannon, M.C. 1985. Principles and strategies in breeding for higher salt tolerance. Plant Soil 89:227-241.

Sharma, S.K., and I.C. Gupta. 1986. Saline environment and plant growth. Agro Botanical Publ. (India), Bikaner, India.

Subbarao, G.V. 1988. Salinity tolerance in pigeonpea (Cajanus cajan) and its wild relatives. Ph.D. diss., Indian Inst. of Technology, Kharagpur, India.

Tal, M. 1985. Genetics of salt tolerance in higher plants: Theoretical and practical considerations. Plant Soil 89:199-226.

Tal, M., and M.C. Shannon. 1983. Salt tolerance in the wild relatives of the cultivated tomato: Responses of Lycopersicon esculentum, $L$. cheesmanii, $L$. peruvianum, Solanum pennellii and $\mathrm{F} 1$ hybrids to high salinity. Aust. J. Plant Physiol. 10:109-117. 